\begin{abstract}
Anita Klapan,
Ph. D.

Siniša Kušić

Faculty of Huma-

nities and Social

Sciences, University

of Rijeka

Danijela Rogić

Medical School,

Rijeka

ABSTRACT

This paper deals with influences of migration on adult education in the Republic of Croatia in the context of lifelong learning. In the introduction we present the most common types of migration in Croatia during the Homeland War. In the second part we present the migration flows occurring during the Homeland War and in the post war period which had a special impact on adult education in the context of lifelong learning. A special emphasis is given to the changes in programmes, organizational forms, didactic-methodical modes and decisions in the education of newly formed groups (refugees and displaced persons). In this paper adult education is shown as an important factor for the development of the culture of peace, which is of great importance for the integration of war migrants. In the end, we give several examples of good practice from the work with displaced persons and refugees promoting the culture of peace as a central notion of education in the last decade of the 20th century.
\end{abstract}

Keywords: war migration, displaced persons, refugees, adult education, culture of peace

\title{
VPLIV MIGRACIJ NA IZOBRAŽEVANJE ODRASLIH NA HRVAŠKEM MED HRVASKKO OSAMOSVOJITVENO VOJNO IN V POVOJNEM OBDOBJU - POVZETEK
}

Članek obravnava vplive migracij na izobraževanje odraslih v Republiki Hrvaški v povezavi z vseživljenjskim učenjem. $V$ uvodu predstavimo najpogostejše vrste migracij na Hrvaškem v času domovinske vojne. V drugem delu prikažemo tiste migracijske tokove, ki so potekali na Hrvaškem v času domovinske vojne in v povojnem obdobju in posebej vplivali na izobraževanje odraslih v okviru vseživljenjskega učenja. Posebno nas zanimajo spremembe v programih, organizacijskih oblikah, didaktično metodičnih pristopih in odločitvah pri izobraževanju na novo oblikovanih skupin (ubežnikov in razseljenih oseb). Članek prikazuje izobraževanje odraslih kot pomemben dejavnik pri razvijanju kulture miru, ki je nadvse pomembna za reintegracijo vojnih migrantov. Na koncu opišemo več primerov dobre prakse pri delu z razseljenimi osebami in ubežniki in spodbujanju kulture miru, osrednjega izobraževalnega koncepta zadnjega desetletja 20. stoletja.

Ključne besede: vojni migranti, razseljene osebe, zavetišča, izobraževanje odraslih, kultura miru

UDK: 374.7

\section{INTRODUCTION}

Migrations are not typical solely of this region and this age. Migrants have in large numbers always been leaving their countries of origin and migrated to other destinations in search of better opportunities or protection from persecution or violence.
International migrations are a complex problem and a major issue of economic and political security of every state. Today most countries are involved in a migration system in which the migration policy of one country affects other countries and makes a firm cooperation between countries imperative in order to gain control of the problem. 
International migrations, involving a wide range of countries of origin, transit and destination as well as various groups of migrants, have become a global phenomenon.

Migrations can be classified according to different criteria, such as voluntariness, distance, duration, organization, migrant motivation, causality and other. With regard to voluntariness, migrations are of two types:

1. voluntary migrations, comprising migrations the aim of which is employment, schooling, family reunion or other personal reasons;

2. forced migrations, comprising migrations that arise from persecution, conflict, war, natural catastrophes, environmental pollution, or other situations posing a threat to human lives, freedom or survival.

The dimension of "force" in migrations refers primarily to "suddenness, surprise", which is not characteristic of "independent" migrations. The notion of force means the absence of time to decide "if" and "when" the migration action should be taken, which would make the process slow and graduate (Mežnarić, 2003, according to Freeman, 1995). A forced migration is, as a rule, a phenomenon of mass migration.

A forced migration is always a process of displacement of population on a large scale, often connected with a catastrophe, the cause of which can derive from two sources: a human or a natural agent, or sometimes both. Due to a possible combination of the two agents and a possible conceptual mistake, we have to distinguish between two notions when describing forced migrations:

- the notion of "ethnic cleansing", and

- the notion of forced migrations (Mežnarić, 2003).
Forced migrations are a broader concept than ethnic cleansing. Ethnic cleansing always entails a forced migration, whereas not all forced migrations result from ethnic cleansing. They can be caused by ecological catastrophes (floods, famine, droughts, volcanic activities), where the agent is the nature or those caused by human activity (toxic waste in industry, terrorism).

The concept of "ethnic cleansing" is generated as a strategy involving "humane displacement" of populations in areas that are being divided due to a division of a federal state. The concept of "humane displacement" has failed as a working strategy of the decision makers and has changed into "escape" of all "other" nationalities, once the political and military actors decided to have "ethnic purity" in a given area.

"Cleansing" of populations is always an "intended, planned activity, the goal of which is to make a population with unwanted characteristics, such as nationality, religion, race, status or gender, leave a certain area. To be classified as "cleansing" an activity has to have at least one of the listed characteristics" (Mežnarić, 2003, according to Bell-Fialkoff, 1996).

In a forced migration, the displaced population cannot choose the time, direction or mode of migrating. With regard to the criterion of distance, migrations can be divided into the two following types:

1. internal migrations, i.e. migrations within the borders of a country (city-village, village-city...).

2. external migrations, i.e. migrations outside the borders of a country.

We have considered migrations only with regard to the criteria of voluntariness and 
distance, because they are of special importance for the migration processes in Croatia during the war and in the post-war era.

\section{CROATIAN MIGRATIONS DURING THE HOMELAND WAR AND IN THE POST WAR PERIOD}

Political events in the former Yugoslavia have largely defined contemporary migrations in Croatia. The types of migration prevailing before the Homeland War (work and transoceanic migrations) have become, in the last twenty years, of secondary importance, both in size and consequences.

When Yugoslavia ceased to exist, the typology of migration changed; the internal migrations (migrations between republics) became external migrations and were governed by different principles and laws; ethnicity became a major factor in the choice of migration destinations. During the last twenty years there were very strong shifts of population due to the war, both within and outside the borders.

War conditions started in different forms in August 1990 and lasted until January 1998. During this time forced war migrations were occurring in Croatia, resulting in large numbers of refugees and displaced persons. The population situation in Croatia was affected at the same time by numerous (forced) migrations caused by the war in Bosnia and Herzegovina, and migrations from other parts of Yugoslavia (Vojvodina and Kosovo). During the last decade of the $20^{\text {th }}$ century Croatia was either the destination or a transit station of hundreds of thousands of inhabitants of those regions, especially of Bosnia and Herzegovina.
It can safely be stated that Croatia and Bosnia and Herzegovina were affected by the largest and most tragic refugee and displaced person crisis after World War Two. The largest burden of accommodating the refugees and displaced persons fell on Croatia and Bosnia and Herzegovina, though they were involved in the war, but also on some other European countries, Germany, Hungary, Austria, Slovenia, and even Yugoslavia.

Picture 1. Directions of displaced person and refugee movements (Domini, 1999)

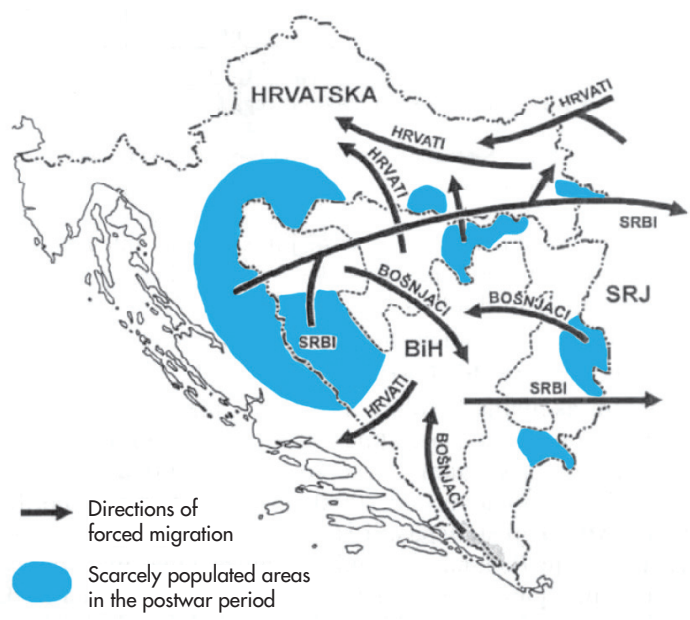

An analysis of the movements of war migrants shows that the main streams of refugees were directed towards Western Croatia and its big cities (Zagreb, Rijeka, Split and partly, Osijek).

The four major and largest migration contingents were the displaced persons, the refugees, the Croatian refugees abroad, and the Croatian refugees in Bosnia and Herzegovina and Yugoslavia. The fact that they were so numerous undoubtedly plays a decisive role in the formation of the present population policy in Croatia. 
The displaced persons are Croatian citizens banished from war-affected areas of Croatia who found temporary accommodation in the parts of Croatia that were not affected by the war. The refugees are the people who were banished from their homes, but found temporary accommodation outside the borders of their country. The displaced persons participated in internal migrations, and refugees in external migrations.

One of the consequences of the war in Bosnia and Herzegovina were large numbers of refugees, which had a significant impact on Croatia. Apart from the refugees from Bosnia and Herzegovina, Croatia was, during the last decade of the $20^{\text {th }}$ century, the intended destination of numerous refugees from Yugoslavia, especially from Vojvodina and Kosovo. The following table shows the number of people in refugee and displaced person contingent in Croatia (including Croatian refugees abroad and Croatian refugees in Bosnia and Herzegovina and Yugoslavia) from 1992 to 1998 (Živić, 1999). frastructure and settlements, which was one of the preconditions for intensification of the return process into Croatia.

The refugee and displaced person movement changed direction after most of the occupied territory was liberated. An organized return campaign began after the military actions "Bljesak" (May 1995) and "Oluja" (August 1995), when the Croatian government devised a return strategy. Many people began to return to or settle in the newly liberated areas. At the same time many Serbs - even though invited to stay and promised amnesty after surrender - left the area following the enemy forces. In that period, the situation in Bosnia and Herzegovina began to improve, and when the Dayton Treaty was signed, a partial return of the refugees from Bosnia and Herzegovina could commence and, thus, the refugee pressure in Croatia decreased.

Since 1991, when the war started, the refugee and displaced person population has been changing. Some of the displaced per-

\begin{tabular}{|c|c|c|c|c|c|c|c|}
\hline \multicolumn{1}{|c|}{ Year } & 1992 & 1993 & 1994 & 1995 & 1996 & 1997 & 1998 \\
\hline Number of refugees and & 764 & 722 & 693 & 591 & 688 & 487 & 409 \\
displaced persons & 206 & 160 & 394 & 123 & 169 & 540 & 156 \\
\hline
\end{tabular}

The war-affected people started returning quite early. The first arrivals of the returnees date back to the beginnings of 1992 when a large number of displaced persons returned to the freed areas of Croatia, which had been affected by intensive war actions before the truce. In the period $1992-1995$ the return of war migrants was sporadic; it was not conceptualized or operational as a state strategy. In the spring of 1994 smaller groups of refugees from Bosnia and Herzegovina started to return to the freed areas of that country, and at that time Croatia embarked on restoration of the in- sons have decided not to return to the homes from which they were banished, but rather settle down permanently in the areas where they lived during the war. Similarly, a part of the refugee population was transformed into immigrant population.

When the war ended, the liberated parts of Croatia were completely devastated. The infrastructure, buildings, churches and schools, were completely or partly destroyed, and, what was even worse, the social system (norms, values, institutions) was also challenged. The war migrants had 
experienced a harsh socio-economic and class deterioration: one day proud, well-off people, the next day needy and dependent. Apart from suffering humiliation, they were confronted with the fact that in the liberated areas there was practically no economic activity, which generated a huge unemployment problem. In this situation institutions became a factor of strong support (especially psychological) for the affected people.

In the post war period public institutions have had a strong symbolic function for war migrants (the returnees), representing a shield against fear (Babić, 2001, according to Berger, 1992) and uncertainty. They are a lighthouse of a kind, showing the path towards a civilized society, providing people with basic security.

The role of institutions, groups and organizations is to articulate and organize the interests of individuals and groups of people. After 1990 the pluralistic scene of Croatia enabled organization and presentation of various interests and their articulation through various types of institutions. Some

\section{A wide network of institutions deal- ing with migra- tion problems.} of the associations, groups and organizations active in Croatia are: Caritas, the Red Cross, the Croatian Helsinki Committee, the Serbian Democratic Forum, the Croatian Phoenix, and the Croatian Disabled Homeland War Veterans Association (HVIDRA). Most of these organizations deal with war immigrants in general; a few, however, specialize and direct their help towards one or two sub-groups of war immigrants.

It can be said that there is a wide network of institutions dealing with migration problems (partly or globally); their cooperation and coordination provides the best results. A similar situation appears in the scientific area, however, only the Institute for Migrations and Ethnic Studies bears the word "migration" in its name, and is the only specialized institution of this kind in Croatia. Other institutes and organizations deal with specific migration flows or specific migration groups. There are also some other institutions that possess valuable data on current and permanent migrations (the Central Bureau of Statistics, Ured za prognanike i izbjeglice Vlade Republike Hrvatske).

\section{ADULT EDUCATION AS AN IMPORTANT FACTOR IN THE DEVELOPMENT OF THE CULTURE OF PEACE}

Apart from having suffered during the war, the affected people are still exposed to severe suffering, caused by primary trauma (physical and mental invalids) or secondary trauma (psychosomatic disorders caused by fear, loss of the beloved ones, loss of property, negative emotions, unemployment, changed social status, problems with inclusion in life in peace, etc).

When the war ended in Croatia and in Bosnia and Herzegovina, the return of war migrants became an important issue for Croatia, especially for the large Croatian refugee and displaced person population. The return has many aspects: political, institutional, security, existential, economic, social, cultural, and psychological.

In most cases life of war migrants in the post-war period does not fit the norms and values of a civil society. The most obvious difference that various groups of returnees and immigrants are experiencing 
in comparison with their pre-war situation is in the field of work and creativity. Work and creative activities as a source of income and satisfaction have been replaced by regular visits to charity organizations.

The existential/economic aspect of this problem is accompanied by the psychological trauma the individuals and groups experience as a result of their low status in the new surroundings. An additional negative factor is stigmatization by local population through stereotypes branding displaced persons and refugees as people who do not want to work.

Reality has brought a great deal of disappointment. A large number of war migrants do not have a permanent job, they have lost their identity, and have serious existential problems. Unfulfilled life ambitions bring frustrations and disappointment, resulting in verbal or physical aggressiveness. In order to feel well and behave well, one has to have certain needs fulfilled, physical as well as psychological. In order to be someone you need to mean something; this is one of the basic human needs.

The psychological aspects of the return, especially the problem of Croats and Serbs living together in one community, were most severe in the period immediately after the war. War wounds were still open, cities and villages destroyed, many people killed or wounded by their former neighbors. Inevitably this made living together in the same community difficult. The question of return implies establishment of a community. The return should entail reconstruction of the local community (in most cases rural), its homogeneity having been destroyed by the war. The traumatic experiences of the returnees, however, make it questionable if this can be accomplished.
One of the most serious consequences of the war is the destruction of primary social networks (friendships, marriages, etc.), which represent the foundation of local communities in relevant areas (Babić, 2004). In the post-war period formation of new networks for primary social interaction is a priority, but due to traumatic experiences the process is very slow and difficult.

In order to revitalize local communities two types of requirement have to be met: material and psychological (Babić, 2004). It is hard to expect that Croats and Serbs will soon be able to have a common life, without problems, including the sensitive forms of social interaction, such as friendship or marriage. Reestablishment of the local community is a precondition for a better life of refugees and displaced persons. Institutionalized forms of restructuring the social scene have an important role in this process.

A revival of local communities has started on the practical level, with material factors in the foreground, renewal of trade, reconstruction of the destroyed infrastructure, help at work, exchange of tools, etc. Sociopsychological factors include memories of positive pre-war experiences of common life and mutual tolerance. A combination of the material and socio-psychological aspects in the reconstruction of the local community can lead to reestablishment of trust between different groups of war migrants, with special emphasis on regeneration of primary social relations networks.

Croatia is a multicultural country. A segment of the population belongs to different ethnic groups, some of which are constituted as minorities with their own collective identity and the aspiration to preserve it. 
Adult education represents an important potential for collaboration between neighboring ethnic groups and nations. It is not only civil education, but a process that could lead to diminishing of the tensions and strengthening of the consciousness that basic problems have the same effect on people of different ethnic backgrounds and that joint actions could help diminish them.

Adult education provides possibilities for learning to help people improve their living conditions and fulfill their needs. In most cases these are the measures that increase their job opportunities or ensure their economic survival. The measures of special significance in the war-affected areas include family planning, hygiene, health education, education for a culture of peace, etc. In this context, the place and role of adult education institutions is prominent.

The culture of peace demands active participation of individuals in establishing a democratic, stabile world, and holds civil society responsible for peace (Spajić-Vrkaš, 1999). Education for peace is directed towards development of active skills or practical use of the acquired knowledge in reallife situations. The culture of peace, one of the central notions of education in the last decade of $20^{\text {th }}$ century, represents a new view of the world, a new system of values, attitudes and behaviors with respect to human rights, human dignity, life, freedom, open civil society, cultural pluralism and tolerance on the one hand, and resistance to violence and nonviolent conflict management on the other.

Such approaches to education are contextually and methodically interwoven and can be classified according to the dominant direction in several fields.
Picture 2. Approaches to education

for a culture of peace

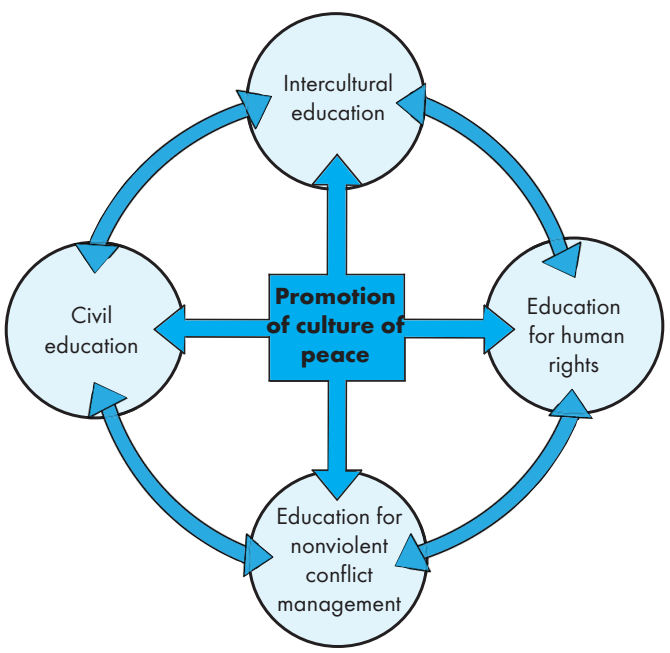

Education for human rights is a term covering a wide range of pedagogical and didacticmethodological instructions, the aim of which is to refer to standards of basic human rights and mechanisms of their protection. If we understand the concept of international standards both as a goal and a means of enabling active participation in promotion and protection of human rights and freedoms, which are a precondition for peace and democracy, we can see that education for human rights is the most comprehensive model in this field.

Education for nonviolent conflict management deals with the principles of peace, development of negotiation skills, dialogue skills, and other skills needed in search for nonviolent solutions in tense or conflict situations.

Civil education is one of the most frequent models. Its goal can be described as preparation for responsible and active citizenship in accordance with the basic principles of liberal democracy and open civil society.

Intercultural (multicultural) education is a term covering a wide range of programmes 
that started in the sixties as a teaching principle or a separate subject in many culturally pluralistic countries in the world. The most important goals of intercultural education are learning about the culture one belongs to, learning about different groups one encounters and about cultural diversity in general, learning about life in a culturally diverse society, strengthening of cultural identity, development of cultural sensitivity and communication skills, overcoming prejudice and stereotypes and tolerance building.

\section{GOOD PRACTICES}

This paper presents good practices implemented in the work with war migrants and the general population during the Homeland War and in the post-war period. The work carried out by the Centre for Peace, Non-Violence and Human Rights has been singled out as an example of good practice in the work with the general population (especially adults); its programmes, projects and activities deserve special attention. Since the work of the Centre in the war and in post war periods was long-lasting and extensive, only an outline of the programmes and projects can be given here. Apart from the programmes, projects and activities described in this paper, the Centre carries out a number of other activities.

The Centre for Peace, Non-Violence and Human Rights, established in 1992 in Osijek, is a non-governmental, non-profitable and nonpolitical association of citizens and one of the first peace organizations established in the war affected part of Croatia. It is a member of the Anti-War Campaign of Croatia.

It has been founded by a group of people (educators, doctors, lawyers and others) during the intensive war actions in the Osijek region in order to build a civil society based on the culture of non-violence and to protect and uphold human rights and liberties, to promote the idea of sustainable peace, tolerance, humaneness, pluralism, pacifism, gender equality, safety of the citizens as well as creative methods of resolving problems and conflicts. The emphasis is placed on the formation of a society based on the culture of peace, which would offer resistance to disruptive ethnic, religious and political conflicts caused by war, and on making the processes of return and integration of communities in the war affected parts of Croatia easier, especially in Eastern Croatia.

All of these goals are being achieved through hard and time-consuming work, contributing a great deal to the individual self-awareness and more humane interpersonal relations as part of process leading to atonement through understanding and appreciation of human dignity. The Centre's activities include work with peace activists, community work, raising awareness of social changes, developing a democratic society based on the culture of peace, helping returnees and other citizens, cooperation with numerous institutions, organizations, associations and initiatives in Croatia and beyond its borders.

In order to achieve its goals, the Centre implements educational and counselling programmes as well as other activities, principles and methods of dealing with reality which promote nonviolence and individual responsibility for social changes stimulating creation and development of a civil society based on the culture of peace.

To bear results, peace work needs to become a continuing educational process within the community. The primary users of the Centre's programmes are peace activists; however, the programmes benefit the entire population (e.g. educators, members of religious communities, 
women, young people, children, war affected people, displaced persons, returnees, refugees, etc.), as all people need to be enabled for responsible integration in social changes and for a modification of the existing conflicts.

Continuing education of peace activists is carried out at different levels; there are special programmes for new members and volunteers and for the already active workers who have not yet completed their training. There are also regular burn-out check-ups and seminars for long-term activists, which are both developmental and relaxing. There is no doubt that peace activists have to cope with serious challenges and that they need to be educated about the importance of life-long learning, good communication, responsibility, cooperation and team work.

The Educational House of the Centre for Peace organizes and implements educational programmes for the wider community, teachers, students, lawyers, members of religious communities, members of different civil committees, institutions and associations. The courses taken at the Centre are recognized as specialization courses for educators. The educational programmes are tailored to the participants' needs, experiences and interests. The Educational House organizes training in many different areas, such as non-violent communication and conflict management, peer mediation and community mediation, creative workshops - education for peace, empowerment of volunteers for peace building and community development, introductory training for women-leaders - empowerment of women for public action, self-aid for war veterans, participatory planning of development of organizations and local communities, listening programmes. Furthermore, it combines training with recreational weekends and takes into account the OKNO-system, which ensures the quality of non-profitable organi- zations. The importance of the Educational House also lies in the fact that it has an active role in setting standards and norms for the training profession.

The activities are carried out through numerous seminars and workshops, where a range of methods for creative problem solving are implemented. These include group work, methods of presentation, dialogue, brainstorming, role playing and many other.

The Centre for Peace follows its aims and objectives through a number of projects included in three correlated programmes:

1. education for peace and psycho-social support,

2. promotion and protection of human rights, 3 . peace building and community development.

\section{Education for peace and psycho-social support}

This programme includes the educational programmes about alternatives to violence, conflict management, communication, protection of human rights, development of democracy with a view of promoting the culture of peace and non-violence as one of the requirements for creating civil society. It also provides help for the victims of war (displaced persons, returnees, refugees, women, children. The programme is intended not only for the victims of war, but also for peace activists, educators and young people. The activities are carried out through several projects, including:

- education for peace and psycho-social development of individuals and community - "Creative Workshops" ("Kreativne radionice"),

- "Steps" (“Koraci”) - a project supporting people who suffer from developmental handicaps, 
- psycho-social support for the young,

- continuing education of activists,

- peace-activist training - empowerment for the peace service.

Education for peace and psycho-social development of individuals and the community - "Creative Workshops" ("Kreativne radionice")

The goal of this project is continuous and systematic education and professional training of teachers, educators and psychologists in order to help them educate children, young people, parents and the war affected population in general. The emphasis is on helping the displaced persons in their return and adaptation to the post-war circumstances.

The purpose is to provide education for peace, cooperation, mutual acceptance, nonviolence, atmosphere of tolerance and understanding creative conflict management for all users of the project. The most frequent problems occurring in work with children, young people, families, returnees, displaced persons and refugees are stress, insecurity, lack of adaptation, resort to violence, problems connected with re-adaptation, financial insecurity and relationships within interfaith marriages.

Three basic goals of working with the users have been achieved through the implementation of the programme:

1. Education of teachers, educationalists, psychologists, volunteers, students through numerous workshops, seminars, courses, supervisory meetings and a range of tests examining a person's selfreliance and ability to take preventive actions and to intervene. The knowledge acquired in the fields of pedagogy, psychology and andragogy enables users for efficient high-quality work.
2. Intervention or direct help provision for children, young people, parents and other who need help through group meetings, therapy talks and a variety of activities designed to alleviate posttraumatic problems.

3. Education for peace, non-violence and protection of human rights for all users of the Programme.

The "Steps" ("Koraci") - a project supporting people suffering from developmental handicaps

The project was launched in late 1998 in order to help and support young people with developmental handicaps, providing them with the company of peers in a safe environment. Its aim has been pursued through a number of workshops directed at changing attitudes, developing self-confidence and self-esteem, facing problems and fears and developing creativity. As a result, the participants have gained self-esteem and have started feeling as equal members of the society.

\section{Psycho-social support for the young}

The activities supporting young people have resulted in their acquiring skills and elements of peace education. Some included organization of field trips.

"The Holiday in Živogošće" ("Ljetovanje $u$ Živogošću"), a project organizing active holidays, was carried out by teachers and peace education trainers. Its purpose was to support the population in the process of return and atonement, so that neighbourly relations and solidarity could be developed. The basic idea was to help the impoverished and traumatized children from Croatia, Serbia and Montenegro, and Bosnia and Herzegovina move away from the devastation caused by the war. It included educational components fostering the process of peace building. Included 
in the project were sporting activities, talk workshops and foreign language courses.

The project "International Youth Camp in Trogen, Switzerland" ("Međunarodni kamp mladih u Trogenu, Švicarska") aimed at bringing together children of different nationalities from different social environments to enhance their creativity and comradeship.

The activities devised in the project "the Play Against Violence" ("Igrom protiv nasilja") enable young people to gain selfesteem and acquire the skills necessary for integration into the civil society. Here professional artists were engaged to help in the work with children and young people who have experienced some form of violence. "The Play Against Violence" gives young people the opportunity to get involved in the experience of play writing and performing as well as learning constructive methods of conflict management. The main tool used was a play; the project leaders had received training, advice and guidance from theatre professionals.

Continuing education of activists and training of peace groups - empowerment of the peace service

Many members and volunteers are involved in continuing education in accordance with their interests and skills. The new members attend various seminars and workshops to receive the basic knowledge, while others expand their knowledge in accordance with their interests, needs and experience. A big advance in the work of the Centre is the education of peace groups. Its main goals are:

- to build a common base and to deepen the understanding of the key values and principles advocated by the project, including non-violence, peace, democracy, empowerment, atonement, etc.,
- to adopt some of the basic skills and tools needed for peace work,

- to form multiethnic teams and to learn about team work,

- to share the vision of the possible future roles peace groups may play in the postwar society (Izvještaj, 1998).

In the course of training a variety of practical activities were performed, such as listening training, fieldwork, TV reports, bulletins, press conferences and article publishing.

The project called "The support centre for the development of local NGOs" ("Centar potpore za razvoj lokalnih NVO-a”) provides support for regional NGOs and other support centres, establishes cooperation, promotes volunteer work and trains volunteers for working in NGOs and for organizing panel and round table discussions.

\section{The programme for promotion and protection of human rights}

This programme is being implemented with the assistance of the Office for the Promotion and Protection of Human Rights and several legal advice centres. It performs a number of activities, such as direct contact with clients, fieldwork for clients, provision of free legal advice and legal assistance, monitoring and advocating human rights, informing the authorised bodies of problems and human rights conditions, cooperation with national and international organizations for protection of human rights, general public education, continuing education of the members of the working team as well as the members of the Centre.

Aid and support are given by various legal advice centres, such as The Counselling Centre for Human Rights, The Counselling Centre for Women, Children and Family's Rights, The 
Counselling Centre for the Victims of War, The Counselling Centre for the Conscientious Objection and Civil Service.

In the war and post-war periods the need for continual fieldwork emerged due to numerous violent incidents, different types of discrimination and the slow process of recovery and return. The most frequent have been the cases related to housing and property rights, citizenship, social, health and status rights, labour rights, pension rights, harassment, eviction, family violence, and problems related to return, stay and emigration.

Promotion of human rights and education of general public are fostered through organization of special activities on significant dates (e.g. Human Rights Day - December 10), through exhibitions, concerts, educational materials, publishing and media campaigns. The members of the Centre and human rights activists receive continuing education through seminars and workshops dealing with different types of legal problems which they might encounter in their work and also by keeping up with legal regulations and analysing them.

\section{The programme of peace and community building}

This programme aims at fostering the peace process and the development of a civil society in the war-torn areas of eastern Croatia. The goals of the programme are development of a multicultural society, democratisation of society, prevention of violence and establishment of security; briefly, development of sustainable peace. The programme supplements the programmes mentioned above.

The work of the Centre aims at the entire population but focuses on the groups that were most affected by the war. It organizes numerous activities the goals of which are preparation for the return of the refugees, alleviation of tensions, communication between groups estranged by the conflict, organization of talk workshops, rebuilding of trust and security, helping Serbs in the process of reintegration, and development of solidarity assistance in the returnees' communities. Special attention is given to the empowering of women, educators, religious groups, youth and peace groups to enable them to carry out the programme.

The programme is being implemented in Eastern and Western Slavonija, Baranja and Western Srijem through the following projects: 1. Building a democratic society based on the culture of non-violence,

2. Rebuilding of trust and return,

3. "Bench Sharing" ("Zajednička klupa"),

4. "Eighty Greenhouses" ("Osamdeset plastenika"),

5. Inter-religious cooperation in the process of peace building,

6. "Women to Women" ("Žene Ženama”).

\section{Building a democratic society based on the} culture of non-violence

The implementation of this project began in 1998 in eastern Croatia and Bosnia and Herzegovina. It was developed to meet the needs of the last phase of the UN Transitional Administration. Its long-term goal is to guide the post-war, post-socialist society towards sustainable peace, security and democracy based on civil participation, pluralism, human rights, minority rights, social justice and sustainable development (Izvještaj, 1999/2001). The project is intended for peace groups, local population, returnees, veterans, members of religious communities, formal and informal community leaders, the Roma minority, women, young people and children. 
The main peace building strategy is community development. All project activities encourage the groups divided by war to work together on fulfilment of their common needs in order to overcome the post-war socioemotional obstacles preventing them from rebuilding the community. The long-lasting conflict and the great rifts in the community make it imperative to permanently support the processes of healing and encouraging the individuals and the community to participate in societal changes. An important part is played by peace groups consisting of international, multiethnic members, which "send a strong message to the community that Croats and Serbs can work together at maintaining peace and rebuilding the community" (Izvještaj, 1999/2001, p.33).

One of the peace groups' tasks was to encourage the local population to participate in peace building activities:

- a listening programme,

- community recovery activities ensuing from the listening programme,

- courses to build trust in the community (e.g. foreign language and computer courses, creative workshops, growing health foods),

- adult education and psycho-social development,

- empowering women, young people and religious communities,

- peace building through media and culture (Izvještaj, 1999/2001).

The peace groups involved were confronted with a great challenge.

To ensure that they would be capable to carry out such a demanding and delicate task, it was necessary to provide them with continuing education, mentors and supervision in different areas, such as strategic planning, organization, training of women for working with women, and self-evaluation.

The first step in the project is a listening programme. Specific programmes were designed for each community to cater for their particular needs and interests. They included adult education, education on democracy and civil society, support groups for women and young people, programmes to enable people for problemsolving and organization of solidarity projects, etc. The aim of the listening programme was to encourage people to interact, to face their problems, and talk freely about their war traumas as well as the current problems and needs, all of which helps them to communicate openly and to cooperate, thus lessening the tensions. The method applied was the interview, conducted by educated listeners.

Once the peace activists acquired sufficient knowledge and experience and became capable of transferring their knowledge and experience to the members of a local community, the listening programme proceeded to the second phase - "the locals listen to the locals". Workshops were held for those who showed interest to join the programme.

Adult education and psycho-social development are important elements in empowering individuals and communities to participate in positive societal changes and in the peace building process. The activities are organized through a series of seminars and thematic workshops.

After the peace groups got integrated in the communities, the ethnically diverse population began attending different courses (foreign languages, computers, creative workshops, growing health food ...). The 
participants shared an impersonal and neutral educational experience, which contributed to the building of confidence among the ethnically diverse population.

Many activities were organized in the attempt to bring together and empower the women in these communities. Despite their traditional upbringing and other factors that infringe their rights, women are more likely to take the initiative and heal families, thus becoming the links between the two sides in the conflict. The most common activities were building of support groups, training for leadership and creative workshops.

Working with young people and children is equally important since they are the foundation of a better future. In the early stages of return the only contacts between the parties in conflict take place in schools; therefore, a thorough preparation of children, parents and teachers was necessary.

Since the religious identity is a also strong factor, closely linked to the national identity, working with members of religious communities and religious leaders needs a great deal of attention in the peace building process.

\section{Rebuilding trust and the return}

The activities fostering trust rebuilding and the return of refugees in Pakrac, Bilje, Okučani, Dalj and Tenja preceded the arrival of peace groups. They dealt with the problems connected with the return of refugees and the restoration of the material goods and the community. They brought individual and group work with the residents, visitation programmes, mediation, legal help and humanitarian aid.

"Bench Sharing” (“Zajednička klupa”)

"Bench Sharing" is a project for trust re- building and establishment of a dialogue between the war-separated groups in Baranja. Its goal and motto is helping individuals and groups "to learn how to live together despite differences". It is based on the tradition of the "divan" (early evening talks) - the inhabitants sharing the benches in front of the their houses to chat in the early evenings (Izvještaj, 1997). This project put the Centre on the list of world organizations dealing with reconciliation.

The activities organized include talk workshops, educational workshops, exchange programmes, cooperation with donors, counselling and mediation between the homeowners and the families temporarily occupying their homes. They are aimed at empowering civil initiatives to work on peace building and promotion of peace and nonviolence. A peace group ("Oaza") has thus been founded in Beli Manastir. Numerous institutions and peace groups provide spiritual, organizational and material aid.

Recently some lectures were held on small businesses to encourage the unemployed in Baranja to start their own small business so as to be able to provide for their families. In addition, educational visits to foreign countries, e.g. the Netherlands, were organized.

\section{“Eighty Greenhouses” (“Osamdeset plaste- nika")}

In 1996, eighty families were taught how to grow vegetables in greenhouses. The goal of the project was to strengthen family budgets and to foster cooperation between the groups divided by the conflict. After receiving further training the participants managed to place their products on local markets, so that most of the families included in the project now make a living by growing and selling vegetables. This means that although 
formally completed, the project is still alive, and, in addition, the friendships thus formed, have remained firm.

\section{Inter-religious cooperation}

Its goal is to encourage religious groups, clergy and lay persons to actively participate in peace building, promoting religious tolerance, and finding ways for religion to serve as a means of reconciliation. These goals are pursued by means of seminars, workshops, round table discussions, ecumenical prayer, etc. The participants are members of different religious communities (Catholics, Eastern Orthodox Christians, Protestants). The programme focuses on women.

\section{“Women for Women” (“Žene Ženama”)}

In 1996, a group of women joined forces to empower other women to participate in implementing positive social changes and the idea of sustainable peace. In 2000, th group took the name "Femina". Their aim is providing help and support for women - victims of family violence, promotion and protection of women's rights, raising the awareness of violence against women as the extreme form of discrimination and violation of women's rights.

At the beginning, the activities focused on the women most at risk - the refugees, but soon a project was launched that catered for all women. Now women are included in the project regardless of their age, level of education, ethnic or religious affiliation. The activities it provides are educational and creative workshops, support groups, telephone counselling (“Women's Line”) and promotion.

Educational workshops covered different topics: Identity Differences, Gender Identity, Women and Work Politics, NonViolent Activities in Light of My Spirituality, Communication Skills, the Alternative to
Violence, Healing through Changes in Attitudes, SOS-Telephone Training. Creative workshops helped women to express themselves through painting on canvas, silk and glass, crocheting and crafting decorations. Support groups bring together women who need support and are ready to work on themselves, build self-confidence and self-respect. The atmosphere of trust, as well as the group dynamics, encourage women to take responsibility for themselves.

By providing all these programmes and projects, panel discussions and by organizing special activities organized on important national and international days, peace activists contribute to public promotion of the culture of peace, tolerance and a pluralistic civil society.

\section{CONCLUSION}

Severe traumas and serious post war problems (existential, legal, socio-economic, etc.) experienced by the polarized groups make a common life in the post war period for them difficult to achieve. Complete reintegration will, therefore, be a slow and long lasting process. Education for development of a culture of peace, tolerance and acceptance of other nationalities is essential for the full reintegration of the population. Contemporary migration processes in Croatia were prompted by the war; people who were forced to move had acquired their education in systems different from those existing in the countries they moved to. In this situation, openness for lifelong learning becomes an important factor, so that the integration of adult immigrants and refugees can continue through various forms of consultation and informal learning. 


\section{REFERENCES}

Akrap, A., Gelo, J., Grizelj, M. (1999). Broj prisutnog stanovništva Republike Hrvatske i županija po dobi i spolu od popisa stanovništva 1991. do 1998. godine. Društvena istraživanja, 5-6: 679-723.

Babić, D. (2001). Institucije i ratni migranti: percepcija aktivnosti i ostvareni kontakti (Brodsko-posavska županija). Migracijske i etničke teme, 1-2: 127-147.

Babić, D. (2004). Suživot Hrvata i Srba u prijeratnom, ratnom i poslijeratnom razdoblju - implicitna kritika interpretacije rata u Hrvatskoj kao etničkog sukoba. Migracijske i etničke teme, 2-3: 187-208.

Barić, N. (ed.) (1993). Djeca u ratu i poslije ratazbornik referata sa savjetovanja. Osijek: Zavod za školstvo Ministarstva kulture i prosvjete Republike Hrvatske.

Bošnjak, B. (1998.). Obrazovanje branitelja - ključ gospodarskog razvitka Republike Hrvatske za 21. stoljeće. Obrazovanje odraslih - časopis za obrazovanje odraslih i kulturu, 1-4: 65-75.

Centar za mir, nenasilje i ljudska prava, Osijek. Retrieved from: (http://www.centar-za-mir.hr

Čudina, M., Težak, D. (1995). Mirotvorni razred: Priručnik za učitelje o mirotvornom odgoju. Zagreb: Znamen.

Domini, M. (1999). Migracijski procesi uzrokovani raspadom Jugoslavije i agresijom na Hrvatsku. Migracijske teme, 3: 323-345.

Hake, J. B., Glastra, F., Schedler, P. (2002). Workers as travelers, migrants and refugees: Border-crossings and the construction of proletarian public spheres in Europe before the Second World War. Paper presented at the $9^{\text {th }}$ International Conference on History of Adult Education, Leiden, August 29-30, 2002.

Izvještaj (1992). Osijek: Centar za mir, nenasilje i ljudska prava. Retrieved from:

(http://www.centar-za-mir.hr/pdf/godisnji\%20izvjestaj1992.pdf)

Izvještaj (1997). Osijek: Centar za mir, nenasilje i ljudska prava. Retrieved from:

(http://www.centar-za-mir.hr/pdf/godisnji\%20izvjestaj\%201997.pdf)
Izvještaj (1998). Osijek: Centar za mir, nenasilje i ljudska prava. Retrieved from:

(http://www.centar-za-mir.hr/pdf/godisnji\%20izvjestaj\%201998.pdf)

Izvještaj (1999/2001). Osijek: Centar za mir, nenasilje i ljudska prava. Retrieved from:

(http://www.centar-za-mir.hr/pdf/godisnji\%20izvjestaj\%201999I2000.pdf)

Izvještaj (2002/2003). Osijek: Centar za mir, nenasilje i ljudska prava.

Izvještaj (2004). Osijek: Centar za mir, nenasilje i ljudska prava.

Jerković, T. (1998). Razvojačeni branitelji u procesu obrazovanja: škola kao čimbenik resocijalizacije branitelja. Obrazovanje odraslih - časopis za obrazovanje odraslih i kulturu, 1-4: 83-85.

Lajić, I. (2002). Hrvatske migracije početkom 21. stoljeća. Migracijske i etničke teme, 2-3: 135-149.

Mežnarić, S. (2003). Migracijske aktualnosti: stanje, problemi, perspektive paradigmi istraživanja. Migracijske i etničke teme, 4: 323-341.

Gartenschlaeger, U., Hinzen, H. (ed.) (2000). Projekt "Doprinosi stabilnosti jugoistočne Europe kroz jačanje lokalnih i regionalnih struktura obrazovanja odraslih”. Zagreb: Hrvatska zajednica pučkih otvorenih učilišta.

Spajić-Vrkaš, V. (1999). Jedinstvo u raznolikosti: Promicanje ljudskih prava i sloboda odgojem i obrazovanjem. Obrazovanje odraslih - časopis za obrazovanje odraslih i kulturu, 1-4: 11-31.

Šakić, V. i dr. (eds.) (1998). Budućnost iseljene Hrvatske. Zagreb: Institut društvenih znanosti Ivo Pilar.

Williamson, B. (1999). Learning in Extremis. In: Alheit, P. et al. (Eds.), Lifelong Learning Inside and Outside School - Second European Conference on Lifelong Learning. Bremen.

Živić, D. (1999). Promjene u dinamici i razmještaju prognaničko-izbjegličkog kontingenta u Republici Hrvatskoj od sredine 1991. do sredine 1998. godine. Društvena istraživanja, 5-6: 767-791.

Živić, D. (2003). Utjecaj srbijanske oružane agresije na etničke promjene u Vukovarsko-srijemskoj županiji od 1991. do 2001. godine. Društvena istraživanja, 6: 1069-1095. 
1 Paper presented at the 10th International Conference on the History of Adult Education, International ESVA Foundation, Helsinki, Finland, September 08-11, 2005. 